\title{
Partai Politik dan Keterwakilan Perempuan (Analisis Problematika Partai Politik dalam Memenuhi Keterwakilan Perempuan di DPRD)
}

\author{
Ana Sabhana Azmy, Isnaini Anis Farhah \\ UIN Syarif Hidayatullah Jakarta, Indonesia \\ E-mail: anasabhanaazmy@gmail.com
}

\begin{abstract}
This research investigates the problems of political parties in meeting the quota of women's representation in Parliament of Lebak Regency for the period 2014-2019. The objectives of this research are to know the importance of women's representation and to analyze the barriers that caused difficulties for political parties to fulfill women's representation in Parliament of Lebak Regency for the period 2014-2019. Method that used in this research is qualitative research with documentation and interview as the data collection technique. Theories used in this research are political party theories by Larry Diamond and women's representation by Anne Phillips and Nadezhda Shvedova. The research found two findings. First, women's representation in Parliament of Lebak Regency is strongly important. Due to the presence of women in Parliament of Lebak Regency can bring women's interests in politics. Second, the importance of women's representation in Parliament of Lebak Regency is not supported by a quota of women's representation in Parliament of Lebak Regency at which only 14\%. There are three barriers that caused difficulties for political parties to fulfill women's representation quota in Parliament of Lebak Regency for the period 2014-2019, namely political barriers, socio-economics barriers, and ideological and psychological barriers.
\end{abstract}

Keywords: women's representation; political party; parliament

\begin{abstract}
Abstrak. Penelitian ini membahas tentang problematika partai politik dalam memenuhi kuota keterwakilan perempuan di DPRD Kabupaten Lebak periode 2014-2019. Tujuan penelitian ini adalah untuk mengetahui pentingnya representasi keterwakilan perempuan dan menganalisis kendala-kendala yang menyebabkan partai politik sulit memenuhi keterwakilan perempuan di DPRD Kabupaten Lebak periode 2014-2019. Metode yang digunakan dalam penelitian ini adalah metode penelitian kualitatif dengan teknik pengumpulan data yaitu studi dokumentasi dan wawancara. Teori yang digunakan adalah teori partai politik dari Larry Diamond dan teori keterwakilan perempuan dari Anne Philips dan Nadezhda Svedova. Hasil penelitian menunjukkan bahwa, pertama, representasi keterwakilan perempuan di DPRD Kabupaten Lebak sangat penting. Hal ini karena dengan hadirnya perempuan di DPRD Kabupaten Lebak dapat membawa kepentingan-kepentingan perempuan dalam politik. Kedua, pentingnya representasi perempuan di DPRD Kabupaten Lebak tidak didukung dengan kuota keterwakilan perempuan di DPRD Kabupaten Lebak yakni hanya 14\%. Ada tiga kendala yang menyebabkan partai politik sulit untuk memenuhi kuota keterwakilan perempuan di DPRD Kabupaten Lebak periode 2014-2019 yaitu kendala politik, kendala sosio-ekonomi, serta kendala ideologis dan psikologis.
\end{abstract}

Kata Kunci: keterwakilan perempuan; partai politik; DPRD

Permalink/DOI: https://doi.org/10.15408/harkat.v14i1.10396 


\section{Pendahuluan}

Isu-isu perempuan di sektor publik akan selalu menarik dan penuh dinamika untuk dikaji, terlebih lagi dalam dunia perpolitikan. Dunia politik di Indonesia identik dengan dunia laki-laki atau politik maskulin. Hal ini terjadi karena politik dianggap sebagai suatu kegiatan yang identik dengan kekuasaan yang bersifat negatif, kesewenangan, kekerasan, pengerahan massa dan kompetisi, dimana kondisi-kondisi itu tidak melekat dalam diri perempuan yang mengutamakan perdamaian (Harmona Daulay, 2007: 34). Kesetaraan gender dalam bidang politik perlu diciptakan demi mewujudkan citacita demokrasi yang mengedepankan prinsipprinsip yaitu prinsip-prinsip keterbukaan, persamaan, kesetaraan, dan keadilan bagi semua warga negara baik laki-laki maupun perempuan untuk dapat berpartisipasi dalam berbagai bidang kehidupan berbangsa dan bernegara (Valina Singka Subekti, 2015: 226).

Kesetaraan gender di bidang politik dapat diwujudkan melalui pemilihan umum. Pelaksanaan pemilihan umum ini tentunya harus menjamin setiap warganya baik itu laki-laki maupun perempuan untuk dapat ikut berpartisipasi sebagai pemilih maupun sebagai calon yang akan dipilih masyarakat nanti. Kesempatan bagi perempuan untuk dapat bebas berpartisipasi dalam politik juga sudah terbuka lebar dan mendapatkan perhatian dari pemerintah Indonesia dengan adanya peraturan perundang-undangan yang menetapkan kuota $30 \%$ pencalonan keterwakilan perempuan. Namun faktanya, adanya peraturan perundangundangan yang mensyaratkan setiap partai politik untuk mencantumkan kuota 30\% bagi pencalonan perempuan, tidak dapat mendongkrak jumlah wakil perempuan untuk duduk di parlemen. Hal ini seperti yang terjadi di DPRD Kabupaten Lebak.

Keterwakilan perempuan di DPRD Kabupaten Lebak masih sangat jauh dari angka
$30 \%$ yakni hanya sebesar 14\%. Di DPRD Kabupaten Lebak, dari 10 partai politik yang berhasil memenangkan kursi, hanya ada empat partai politik yang berhasil memenuhi keterwakilan perempuan yaitu PPP, Partai Nasdem, PDIP, dan PKS. Enam partai politik lainnya yaitu Partai Golkar, PAN, PKB, Partai Gerindra, Partai Demokrat, dan Partai Hanura tidak berhasil untuk memenuhi kuota keterwakilan perempuan di DPRD Kabupaten Lebak periode 2014-2019.

Minimnya jumlah perempuan yang duduk di DPRD Kabupaten Lebak dan tidak adanya keterwakilan perempuan dari enam partai politik tersebut, mengindikasikan bahwa partai-partai politik di Kabupaten Lebak kurang memperhatikan keterwakilan perempuan di parlemen. Partai politik merupakan kendaraan yang tepat untuk dapat mengantarkan perempuan ke lembaga legislatif, sudah seharusnya partai politik mempunyai komitmen untuk dapat memasukkan caleg perempuannya ke parlemen.

\section{Metode}

Metodologi penelitian yang digunakan adalah metode penelitian kualitatif. Metode penelitian kualitatif adalah suatu jenis penelitian yang menghasilkan penemuan-penemuan yang tidak dapat dicapai dengan menggunakan prosedur-prosedur statistik.

Penelitian ini menggunakan 2 (dua) teknik pengumpulan data yaitu studi dokumentasi dan wawancara. Teknik analisis data yang digunakan adalah model analisis deskriptif.

\section{Hasil dan Pembahasan}

\section{Urgensi Representasi Perempuan di Kabupaten Lebak}

Berdasarkan data dari Badan Pusat Statistik (BPS) tahun 2014, jumlah penduduk di 
Indonesia mencapai 210 juta jiwa, dengan lebih dari setengahnya adalah penduduk perempuan. Meskipun jumlah penduduknya mayoritas perempuan, akan tetapi perwujudan kesetaraan dan keadilan gender antara laki-laki dan perempuan masih terhambat. Dalam beberapa aspek, ketidakadilan dan ketimpangan peran perempuan masih sangat banyak ditemukan, seperti yang terjadi di daerah Kabupaten Lebak. Di Kabupaten lebak, ketidakadilan dan ketidaksetaraan gender masih sangat banyak ditemukan. Gambaran mengenai permasalahanpermasalahan yang dialami oleh kaum perempuan di Kabupaten Lebak dapat dilihat pada uraian di bawah ini.

\section{Tingkat Pendidikan Perempuan}

Salah satu cerminan dari kesejahteraan masyarakat adalah tingginya masyarakat yang mampu untuk melaksanakan pendidikan. Berdasarkan data dari BPS Kabupaten Lebak, angka partisipasi sekolah di Kabupaten Lebak menunjukkan perbedaan yang signifikan antara laki-laki dan perempuan. Untuk lebih jelasnya dapat dilihat pada tabel di bawah ini.

Gambar 1. Angka Partisipasi Sekolah Penduduk Berumur 5-18 Tahun menurut Jenis Kelamin dan Kelompok Umur Tahun 2015

\begin{tabular}{lll}
\hline $\begin{array}{l}\text { Kelompok } \\
\text { Umur }\end{array}$ & Laki-laki & Perempuan \\
\hline $5-6$ & 26.86 & 34.62 \\
$7-12$ & 97.26 & 100.00 \\
$13-15$ & 94.11 & 90.37 \\
16-18 & 57.23 & 55.97 \\
\hline Sumber: Badan Pusat Statistik Kabupaten Lebak
\end{tabular}

Berdasarkan gambar di atas, angka partisipasi sekolah di Kabupaten Lebak tahun 2015 mempunyai perbedaan di setiap kelompok umurnya. Dalam kelompok umur 5-6 tahun dan 7-12 tahun, angka partsipasi sekolah kaum perempuan lebih tinggi dibandingkan dengan laki-laki, sedangkan kelompok umur 13-15 tahun dan 16-18 tahun, angka partisipasi sekolah kaum perempuan lebih rendah. Namun, pada tahun berikutnya yaitu tahun 2016, angka partisipasi sekolah kaum perempuan di setiap kelompok umurnya lebih tinggi dari kaum lakilaki. Lebih jelasnya, lihat tabel di bawah ini:

Gambar 2. Angka Partisipasi Sekolah Penduduk

Berumur 5-18 Tahun menurut Jenis Kelamin dan Kelompok Umur Tahun 2016

\begin{tabular}{lll}
\hline Kelompok Umur & Laki-laki & Perempuan \\
\hline 5-6 & 13.24 & 27.33 \\
$7-12$ & 97.38 & 98.68 \\
$13-15$ & 94.39 & 94.81 \\
$16-18$ & 45.85 & 60.34 \\
\hline
\end{tabular}

Sumber: Badan Pusat Statistik Kabupaten Lebak

Pada tahun 2017, berdasarkan data yang diperoleh dari BPS Kabupaten Lebak, angka partisipasi sekolah mengalami penurunan kembali dibandingkan dengan tahun sebelumnya dan mempunyai perbedaan yang signifikan dengan angka partisipasi sekolah kaum laki-laki. Dalam kelompok umur 16-18 tahun perbedaan angka partisipasi sekolah antara laki-laki dan perempuan cukup tinggi yaitu berbeda 9,86\% dan sangat berbeda jauh bila dibandingkan dengan tahun 2016 yang memperoleh 60.34\% untuk angka partisipasi sekolah kaum perempuan. Persentase angka partisipasi sekolah pada tahun 2017 di Kabupaten Lebak dapat dilihat pada tabel di bawah ini:

Gambar 3. Angka Partisipasi Sekolah Penduduk

Berumur 5-18 Tahun menurut Jenis Kelamin dan Kelompok Umur Tahun 2017

\begin{tabular}{lll}
\hline $\begin{array}{l}\text { Kelompok } \\
\text { Umur }\end{array}$ & Laki-laki & Perempuan \\
\hline $5-6$ & 28.71 & 27.97 \\
$7-12$ & 98.90 & 98.36 \\
$13-15$ & 96.19 & 90.27 \\
$16-18$ & 50.29 & 40.43 \\
\hline
\end{tabular}

Sumber: Badan Pusat Statistik Kabupaten Lebak 


\section{Tingkat Kesehatan Perempuan}

Hak dasar lain yang luput dari perhatian selama ini adalah hak atas kesehatan. Tingginya tingkat kematian ibu melahirkan dan balita adalah penanda dari buruknya pemenuhan atas hak dasar tersebut.

Gambaran rinci mengenai angka kematian ibu di Kabupaten Lebak adalah sebagai berikut:

Gambar 4. Grafik Angka Kematian Ibu di Kabupaten Lebak

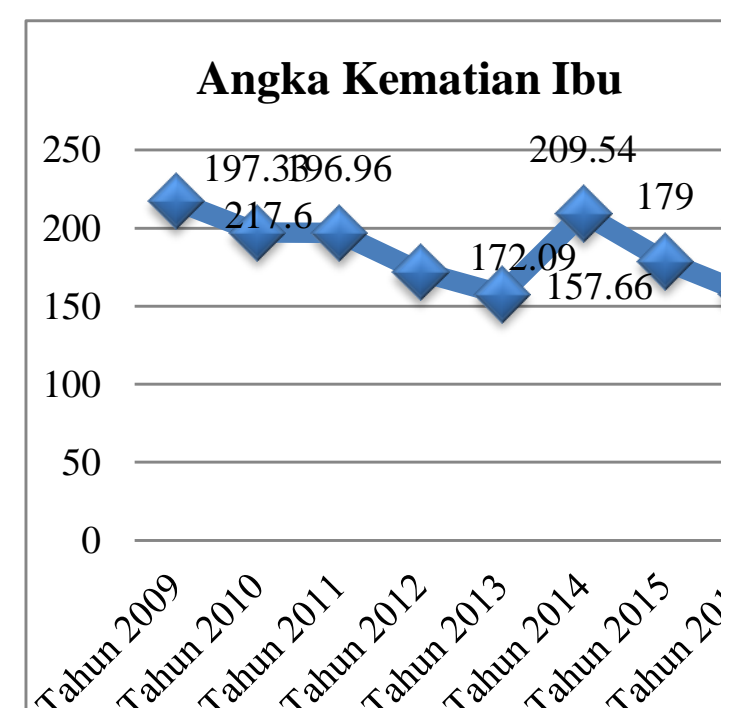

Sumber: Dinas Kesehatan Kabupaten Lebak

Berdasarkan grafik di atas, dapat dilihat bahwa angka kematian ibu setiap tahunnya sering mengalami kenaikan dan penurunan. Dengan laju tingkat angka kematian ibu yang tidak signifikan tersebut, hal ini patut mendapat perhatian agar di tahun-tahun berikutnya angka kematian ibu dapat terus ditekan sehingga jumlahnya dapat semakin menurun. Pengabaian terhadap hak kesehatan reproduksi perempuan berakibat pada keterbatasan kesempatankesempatan bagi perempuan.

Tingkat Kekerasan Terhadap Perempuan
Perempuan menempati posisi yang rentan terhadap masalah kekerasan. Permasalahan kekerasan walaupun sudah sering terjadi, tetapi masih belum ditanggapi secara serius karena dianggap sebagai urusan pribadi seseorang. Salah satu daerah di Indonesia yang sering mengalami permasalahan kekerasan dan membutuhkan perhatian adalah di Kabupaten Lebak. Kasus kekerasan di Kabupaten Lebak mengalami peningkatan dari 21 kasus yang terjadi pada tahun 2013 menjadi 31 kasus pada tahun 2014 (Antara

Banten,https://banten.antaranews.com/berita/21 911/kasus-kdrt-di-lebak-meningkat, diakses pada 11 Juni 2018).

Pada tahun 2015, kasus kekerasan di Kabupaten Lebak menurun bila dibandingkan dengan tahun-tahun sebelumnya yaitu menjadi 23 kasus

(Inilahcom,https://inilah.com/news/detail/2267 863/meononjol-korban-kekerasan-seks-anak-dilebak, diakses pada 29 Juni 2018).

Pada tahun 2016, terdapat 20 kasus kekerasan yang terjadi di Kabupaten Lebak dan korbannya kebanyakan menimpa anak-anak perempuan

(Suaracom,http://suara.com/news/2016/11/20/0 21800/kekerasan-seksual-di-lebak-makin-maraktahun-ini, diakses pada 29 Juni 2018)

Pada tahun 2017, kasus kekerasan mengalami peningkatan kembali dan tahun 2017 merupakan kasus kekerasan yang tertinggi bila dibandingkan dengan tahun-tahun sebelumnya. Di tahun 2017, terdapat 32 kasus kekerasan seksual di Kabupaten Lebak dan mayoritas korban dari banyaknya kasus di tahun 2017 adalah anak-anak perempuan (Seruji, https://seruji.co.id/daerah/dki-banten/pemkablebak-minta-orangtua-awasi-penggunaan-gadgetpada-anak, diakses pada 29 Juni 2018).

Permasalahan-permasalahan yang melanda Kabupaten Lebak di atas tersebut telah banyak mempengaruhi kehidupan kaum perempuan dan 
anak-anak. Hal tersebut telah meningkatkan kesadaran tentang perlunya menyusun sebuah agenda politik yang lebih responsif gender. Hadirnya dan terlibatnya kaum perempuan dalam dunia politik diharapkan dapat mendengarkan persoalan dan peduli terhadap isu-isu permasalahan, khususnya yang terkait kepentingan kaum perempuan. Sebagaimana yang diungkapkan oleh caleg perempuan dari Partai Keadilan Sejahtera (PKS) yang berhasil lolos untuk duduk di DPRD Kabupaten Lebak periode 2014-2019 yaitu Hj. Esih Sukaesih yang mengatakan bahwa:

Pandangan saya terkait pentingnya representasi perempuan dalam parlemen bahwa sesuai dengan peraturan Undang-Undang yang mengamanatkan kepada kaum perempuan itu untuk menduduki jabatan politis atau jabatan posisi yang ada di parlemen minimal 30\%. Kenapa diamanahkan 30\%, karena memang, yang pertama perlu menyuarakan keterwakilan tentang hak-hak kaum perempuan sehingga dengan adanya representasi perempuan di parlemen, kita bisa menyampaikan aspirasi terkait tentang perempuan. Kemudian, kita juga bisa membuat regulasi atau kebijakan yang berpihak kepada kaum perempuan, misalnya terkait dengan perubahan terhadap perempuan (Hj. Esih Sukaesih, wawancara pribadi, 18 Januari 2018).

Pernyataan di atas tersebut sesuai dengan teori yang dikemukakan oleh Anne Philips yang mengatakan bahwa representasi perempuan dalam parlemen sangat penting karena dengan adanya representasi perempuan maka akan membawa pada kepentingan-kepentingan perempuan dalam politik yang dimana perempuan memiliki kepentingan-kepentingan yang berbeda dari laki-laki. Dengan kiprah perempuan dalam politik, maka akan memberi contoh terhadap perempuan lainnya untuk lebih percaya diri yang kemudian dapat membongkar akar-akar asumsi yang menyatakan hal-hal yang tepat dan tidak tepat bagi perempuan (Anne Philips, 1995: 62).

Oleh karena itu, mengingat pentingnya representasi perempuan, maka sudah seharusnya partai politik memiliki komitmen yang kuat untuk memasukkan calon anggota legislatif perempuannya untuk duduk di parlemen, karena partai politik merupakan institusi yang paling penting dalam upaya peningkatan keterwakilan perempuan.

Namun, berdasarkan hasil analisis penelitian, jumlah perempuan yang berada di DPRD Kabupaten Lebak pada periode 20142019 tidak menyentuh angka 30\% yakni hanya sebesar $14 \%$.

\section{Kendala-Kendala Penyebab Partai Politik Tidak Memenuhi Keterwakilan Perempuan di DPRD Kabupaten Lebak Periode 2014-2019}

Keterbatasan partai politik dalam mengimplementasikan 30\% angka keterwakilan perempuan dikarenakan adanya berbagai kendala sehingga partai politik sulit untuk memenuhi keterwakilan tersebut, dan tidak dapat meloloskan calon anggota legislatif perempuannya untuk duduk di DPRD Kabupaten Lebak periode 2014-2019. Adapun kendala-kendala tersebut adalah seperti yang dikemukakan oleh Nadezhda Shvedova, yang diantaranya adalah:

\section{Kendala-Kendala Politik}

\section{Kurangnya dukungan partai politik}

Dukungan dari partai politik memainkan peran yang sangat penting dalam menempatkan kader perempuannya untuk dapat lolos ke parlemen. Namun, walaupun partai politik adalah institusi politik yang melakukan implementasi kebijakan 30\% keterwakilan, tetapi hal tersebut tidak membuat partai politik memiliki komitmen untuk melaksanakan 
kebijakan untuk meraih angka 30\%. Hal tersebut dapat terlihat seperti yang ada di DPRD Kabupaten Lebak. Di DPRD Kabupaten Lebak periode 2014-2019, bahwa dari total 10 partai politik yang berhasil memenangkan kursi, hanya ada 4 (empat) partai politik yang berhasil meloloskan caleg perempuannya, sedangkan 6 (enam) partai politik lainnya tidak berhasil menempatkan caleg perempuannya untuk duduk di kursi DPRD Kabupaten Lebak periode 20142019.

Hal ini mengindikasikan bahwa partai politik kurang mendukung kader perempuannya yang mencalonkan diri pada pemilihan umum legislatif tahun 2014. Kurangnya dukungan dari partai politik akan sangat berpengaruh terhadap hasil perolehan suara dan juga akan berpengaruh terhadap jumlah perempuan yang ada di parlemen. Hal ini seperti yang dikatakan oleh Djudju Yumiarsih:

Faktor partainya ya pengaruh dalam menempatkan ibu disini, karena kan ibu bernaung di partai besar Partai Persatuan Pembangunan yang notabene ada pemilihpemilih militan (Djudju Yumiarsih, wawancara pribadi, 31 Januari 2018).

Oleh karena itu, partai politik sebagai pelaksana kebijakan dalam meraih angka 30\% harus memberikan dukungan dan menunjukkan komitmen yang kuat untuk dapat menempatkan caleg perempuannya agar bisa lolos ke parlemen.

a) Model maskulin politik dan proses seleksi yang bias gender

Politik selalu dihubungkan dengan hal-hal yang bersifat maskulin yang dianggap berebda dengan sifat-sifat yang dimiliki oleh pereempuan. Dalam hal ini, perempuan dianggap tidak cocok untuk terjun ke dunia perpolitikan, karena citra perempuan yang dinilai lemah lembut, tidak kuat, tidak tegas, sehingga bertentangan dengan citra politik yang keras dan cenderung menghalalkan segala cara (Siti Hariti Sastriyani, 2009: 167).

Untuk pencalegan ini kan hampir ratarata, tidak hanya PKB saja ya, itu didominasi oleh laki-laki, perempuannya juga kalau tidak salah hanya 5 (lima) atau 6 (enam) yang duduk di parlemen. Kalau PKB kebetulan dari 6 (enam) daerah pemilihan (dapil) yang terisi 5 (lima) dapil jadi PKB dapat 5 (lima) kursi semuanya itu laki-laki yang mewakilinya, kalau perempuan memang tidak ada (Ari Firdausyi, wawancara pribadi, 31 Januari 2018).

Dengan adanya persepsi negatif tentang perempuan tersebut, hal ini menyebabkan tidak sedikit partai politik yang mengutamakan karakteristik laki-laki dalam proses seleksi untuk duduk di parlemen dan tentunya menjadi penghambat bagi pemenuhan 30\% keterwakilan perempuan di parlemen. Dalam fenomena model maskulin politik ini karena dunia politik identik dan didominasi oleh kaum laki-laki maka tidak menutup kemungkinan pada proses seleksi dalam persoalan nomor urut, masih banyak partai politik yang menekankan bias gender, dalam arti partai politik masih menempatkan nomor urut untuk laki-laki di atas sedangkan nomor urut. Mayoritas partai politik menempatkan calon perempuannya berada dalam nomor tengah dan nomor terakhir yang punya peluang sangat kecil untuk terpilih (Ani Widyani Soetjipto, 2005: 33).

b) Kurangan hubungan dan kerjasama dengan organisasi publik maupun lembaga swadaya masyarakat lainnya

Hubungan kerjasama yang dilakukan pada saat kampanye pemilihan umum memiliki potensi yang sangat besar dalam meningkatkan perolehan suara, terlebih lagi untuk caleg perempuan. Jika caleg-caleg perempuan melakukan kerjasama dengan organisasi publik maka hal ini akan menggalang dukungan dalam rangka memperjuangkan kepentingankepentingan perempuan. Namun, sayangnya 
para caleg-caleg perempuan, khususnya caleg perempuan yang dinominasikan di pemilihan umum legislatif tahun 2014 lalu di Kabupaten Lebak masih kurang dalam melakukan kerjasama dengan organisasi-organisasi publik, sehingga hal ini akan menjadi kendala jika kader perempuan dari suatu partai politik dinominasikan di pemilihan umum (Nina Andriana, 2012: 8). Seperti yang dikatakan oleh Bendahara Umum dari PKB yaitu Ari Firdausyi mengatakan bahwa:

Perempuan yang belum berorganisasi dan kurangnya hubungan dengan organisasi itu ketika menemui masyarakat banyak akan kaget, tidak bisa ngomong atau gimana atau gugup sehingga akan sulit untuk bersosialisasi terutama kepada masyarakat, apalagi saat kampanye pemilu (Ari Firdausyi, wawancara pribadi, 31 Januari 2018).
c) Sistem pelatihan kaderisasi dan pendidikan politik

Pelatihan kaderisasi dan pendidikan politik sangat penting karena melalui pelatihan kaderisasi dan pendidikan politik inilah diharapkan nantinya akan lahir kader yang berkualitas. Dalam hal ini, partai politik harus ikut membantu kaderisasi dan pendidikan politik terutama kepada kader perempuan agar kader perempuan yang dinominasikan oleh partainya dalam pemilihan umum memiliki kualitas yang baik. Namun nyatanya berdasarkan hasil wawancara, walaupun partai politik sudah melakukan pelatihan kaderisasi dan pendidikan politik, minat perempuan untuk terjun ke politik juga masih belum maksimal. Seperti yang dikatakan oleh:

Kita sudah melakukan kaderisasi dan pendidikan politik dengan mengadakan rapat. Dalam rapat ini, kader PAN diberikan materimateri. Namun, mayoritas, kaum perempuan tidak hadir. Lebih baik istirahat, daripada buat apa mendengarkan, karena kalau sudah jadi belum tentu. Alasannya kan seperti itu, jadi ya sumber daya manusia kendala buat kita (Agus Sumantri, wawancara pribadi, 7 Maret 2018).

Dalam partai politik, kaderisasi merupakan kebutuhan internal yang tidak boleh tidak dilakukan. Seorang kader dari partai politik diharapkan memiliki daya tahan perjuangan karena pada dasarnya, proses kaderisasi dan pendidikan politik bukan merupakan proses yang cepat, akan tetapi berjenjang, sistematik, dan dilakukan secara terus-menerus. Oleh karena itu, kader-kader dari partai politik yang dinominasikan dalam pemilihan umum haruslah konsisten dalam menjalankan proses kaderisasi dan pendidikan politik.

\section{Kendala Sosio-Ekonomi}

Dalam kendala sosio-ekonomi ini beban ganda juga menjadi kendala yang membuat partai politik sulit untuk memasukkan caleg perempuannya untuk duduk di parlemen. Kondisi perempuan yang memiliki beban ganda ini membuat tidak semua perempuan mampu melakukannya. Hal ini diungkapkan oleh $\mathrm{H}$. Yaya Suharya:

Disambut atau tidak, berapa banyak yang tertarik, kalau mereka tertarik untuk berpartisipasi, mereka pasti punya banyak pertimbangan, punya sisi kendala. Kendalanya ya pas nyalon mereka kurang sosialiasi, karena kan banyaknya ibu rumah tangga, ada keterbatasan-keterbatasan waktu. Mereka mampu tidak untuk mengatur waktu antara kesibukkan ibu rumah tangga, kemudian mengurus partai politik agar hak-haknya bisa seimbang (H. Yaya Suharya, wawancara pribadi, 31 Januari 2018).

Keterbatasan waktu inilah yang kemudian menjadi kendala yang dialami oleh partai-partai politik yang ada di Kabupaten Lebak sulit untuk menempatkan caleg perempuannya untuk bisa lolos ke DPRD Kabupaten Lebak. Dengan adanya beban ganda yang dialami oleh kaum perempuan, maka tidak banyak perempuan yang 
ingin terjun ke dalam dunia politik, terlebih lagi untuk terjun ke dalam dunia politik, ekonomi dari caleg perempuannya juga memainkan peran yang sangat penting. Dalam dunia politik juga membutuhkan banyak biaya, karena partai politik mempunyai banyak agenda seperti mengikuti pelatihan, mengikuti rapat, dan biaya yang lebih besar pada saat mengikuti kampanye pemilu.

Berpolitik itu membutuhkan biaya, paling tidak biaya transport. Jika ikut rapat, pelatihan, ikut kampanye, dan lain sebagainya darimana uangnya karena kan sebagian besar di daerah financial berasal dari suaminya (Lilis Suganda, wawancara pribadi, 27 Februari 2018).

Jika perempuan tidak mendapatkan izin ekonomi baik dari suami maupun keluarganya maka tidak menutup kemungkinan caleg perempuan tersebut tidak dapat terjun ke dunia politik.

\section{Kendala ideologis dan psikologis}

Ideologi gender dan pola-pola kultural yang ada dan berkembang di dalam masyarakat merupakan faktor yang penting dalam menentukan perolehan suara bagi caleg perempuan pada pemilihan umum. Dalam hal ini, masyarakat menganggap bahwa tempat perempuan adalah pada ranah domestik atau privat, sedangkan politik adalah ranah publik yang biasanya secara kuantitas lebih banyak lakilaki daripada perempuan. Permasalahan ini seringkali menjadi masalah bagi partai politik untuk memasukkan caleg perempuannya untuk duduk di kursi parlemen, khususnya di DPRD Kabupaten Lebak. Dewi Indriyati mengatakan:

Iya sepertinya faktor ideologi dan pola kultural jadi penghambat juga, karena asumsi kesana itu memang agak melekat dan kuat juga di daerah, terkecuali seperti di kota-kota besar mungkin daya pikirnya juga sudah lain (Dewi Indriyati, wawancara pribadi, 21 Februari 2018).
Perempuan yang dihadapkan oleh ideologi gender dan pola-pola kultural maupun peran sosial kemudian akan berakibat pada kurangnya kepercayaan diri perempuan untuk mencalonkan diri atau enggan terlibat dalam dunia politik.

\section{Simpulan}

Berdasarkan hasil pembahasan di atas, maka dapat ditarik kesimpulan bahwa representasi keterwakilan perempuan di DPRD Kabupaten Lebak sangat penting. Dengan meningkatnya representasi keterwakilan perempuan di parlemen, diharapkan dapat membawa kepentingan-kepentingan perempuan dalam politik dan dapat mendengarkan permasalahan-permasalahan yang terjadi di Kabupaten Lebak, seperti permasalahan tingkat pendidikan, tingkat kesehatan, dan tingkat kekerasan.

Namun, pentingnya representasi keterwakilan perempuan di Kabupaten Lebak tidak seimbang dengan jumlah perempuan yang duduk di DPRD Kabupaten Lebak. Jumlah perempuan di DPRD Kabupaten Lebak periode 2014-2019 hanya 7 (tujuh) dari total 50 orang dengan jumlah keterwakilan perempuan yakni sebesar 14\%. Ada 3 (tiga) kendala yang menyebabkan partai politik sulit untuk memenuhi kuota keterwakilan peermpuan di DPRD Kabupaten Lebak periode 2014-2019 yaitu kendala politik, seperti kurangnya dukungan dari partai politik, masih melekatnya model maskulin politik dan proses seleksi yang bias gender, kurangnya hubungan kerjasama dengan organisasi publik, dan kurangnya sistem pelatihan kaderisasi dan pendidikan politik. Selain kendala politik, kendala-kendala lainnya adalah karena kendala sosio-ekonomi yakni adanya beban ganda dan kurangnya izin ekonomi dari keluarga, serta kendala ideologis dan psikologis, seperti masih melekatnya ideologi gender dan pola-pola kultural yang berkembang di masyarakat. 


\section{Daftar Pustaka}

Antara Banten, Kasus KDRT di Lebak Meningkat [artikel on-line], tersedia di https://banten.antaranews.com/berita/2191 1/kasus-kdrt-di-lebak-meningkat diakses pada 11 Juni 2018.

Andriana, Nina dkk, Perempuan, Partai Politik, dan Parlemen: Studi Kinerja Anggota Legislatif Perempuan di Tingkat Lokal, (Jakarta: PT. Gading Inti Prima, 2012).

Daulay, Harmona, Perempuan dalam Kemelut Gender, (Medan: USU Press, 2007).

Inilahcom, Menonjol, Korban Kekerasan Seks Anak di Lebak [artikel on-line], tersedia di https://inilah.com/news/detail/2267863/m eononjol-korban-kekerasan-seks-anak-dilebak diakses pada 29 Juni 2018.

Philips, Anne, The Politics of Presence: The Political Representation of Gender, Ethnicity, and Race, (New York: Oxford University Press, 1995).

Sastriyani, Siti Hariti, Gender and Politics, (Yogyakarta: Tiara Wacana, 2009).

Seruji, Pemkab Lebak Minta Orangtua Awasi Penggunaan Gadget Pada Anak [artikel online], tersedia di https://seruji.co.id/daerah/dkibanten/pemkab-lebak-minta-orangtuaawasi-penggunaan-gadget-pada-anak diakses pada 29 Juni 2018.

Suaracom, Kekerasan Seksual di Lebak Makin Marak Tahun Ini [artikel on-line], tersedia di

http://suara.com/news/2016/11/20/02180

0/kekerasan-seksual-di-lebak-makin-maraktahun-ini diakses pada 29 Juni 2018.

Subekti, Valina Singka, Dinamika Konsolidasi Demokrasi: Dari Ide Pembaruan Sistem Politik Hingga ke Praktik Pemerintahan Demokratis, (Jakarta: Yayasan Pustaka Obor Indonesia. 2015).
Wawancara pribadi dengan Agus Sumantri (Ketua DPD PAN Kabupaten Lebak) pada 7 Maret 2018 di Kantor DPD PAN Kabupaten Lebak.

Wawancara pribadi dengan Ari Firdausyi (Bendahara Umum DPC PKB Kabupaten Lebak) pada 31 Januari 2018 di Kantor DPC PKB Kabupaten Lebak.

Wawancara pribadi dengan Dewi Indriyati.(Caleg Perempuan tidak jadi dari DPC Partai Gerindra Kabupaten Lebak) pada 21 Februari 2018 di Kantor DPC Partai Gerindra Kabupaten Lebak.

Wawancara pribadi dengan Djudju Yumiarsih, SE. (Anggota Legislatif Perempuan dari DPC Partai Persatuan Pembangunan Kabupaten Lebak) pada 31 Januari 2018 di Kantor DPRD Kabupaten Lebak.

Wawancara pribadi dengan H. Yaya Suharya (Wakil Ketua Bidang OKK DPD Partai Golkar Kabupaten Lebak) pada 31 Januari 2018 di Kantor DPD Partai Golkar Kabupaten Lebak.

Wawancara pribadi dengan $\mathrm{Hj}$. Esih Sukaesih, SE. (Anggota Legislatif Perempuan dari DPC Partai Keadilan Sejahtera Kabupaten Lebak) pada 18 Januari 2018 di Kantor DPRD Kabupaten Lebak.

Wawancara pribadi dengan Lilis Suganda (Sekretaris DPC PKS Kabupaten Lebak) pada 27 Februari 2018 di Kantor DPD PKS Kabupaten Lebak.

Widyani, Ani Widyani, Politik Perempuan Bukan Gerhana, (Jakarta: Buku Kompas, 2005). 